\title{
A Most Fortunate Court Martial: The Trial of Captain Charles Kingsmill, 1907.
}

\section{Robert L. Davison}

En août 1906 le cuirassé britannique HMS Dominion a échoué sur un haut-de-fonds sur la côte nord de la Baie des Chaleurs. Son capitaine, Charles Edmund Kingsmill, était un Canadien qui est entré dans la marine royale en 1869, quand il avait 13 ans. Kingsmill a été traduit en cour martiale pour cet échouage au début de 1907, et a été trouvé coupable. Bien qu'il ait reçu une peine légère, ses perspectives de carrière dans le service britannique se sont trouvées limitées. Sont présentés ici les documents principaux de la cour martiale déposés aux archives nationales du Royaume-Uni. Le rédacteur argue du fait que la cour martiale était un facteur dans la décision de Kingsmill peu après d'accepter une position avec le gouvernement canadien, d'abord en tant que directeur du service de protection de la pêche, et puis, en 1910, en qualité de premier directeur du nouveau service naval du Canada.

Charles Edmund Kingsmill, the first director of the Naval Service of Canada, served as an officer in the Royal Navy from the age of 13. Born in Guelph, Canada West on 7 July 1855, he was the son of John Juchereau Kingsmill, crown attorney of Wellington County and judge of Bruce County. As a young man, Charles attended Upper Canada College in Cobourg and took advantage of a colonial appointment to the cadet ship HMS Britannia in September 1869. Kingsmill gradually moved up through the ranks of the service. He became a midshipman in June 1871, a sub-lieutenant in December 1875 and lieutenant in 1878. Promotion to commander and captain was strictly by selection and by 1892 after 14 years' seniority (somewhat late but still within the zone of promotion) he became a commander. In 1898, he reached what many considered the pinnacle of a naval career by being promoted to the rank of captain at the age of 43 . By 1906, Kingsmill was reaching near the top of the seniority list in that rank and had a good chance of being able to hoist his flag as a rear-admiral within the next two or three years. ${ }^{1}$

Kingsmill's career, however, took a turn for the worse when the ship under his

1 Promotion from captain to rear-admiral was still by seniority. As long as an officer had sufficient sea time in command "of a ship at war at sea" he was virtually guaranteed to become a flag officer either on the active or retired list.

The Northern Mariner/le marin du nord, XIX No. 1, (January 2009), 57-86 
command, the new battleship HMS Dominion, ${ }^{2}$ grounded in Chaleur Bay in August 1906. The ship was on detached service carrying out a program of good will tours around the Canadian Atlantic coast and was ultimately bound for Quebec where there would be a special presentation of plate and other accoutrements to fit out the messes and the captain's quarters.

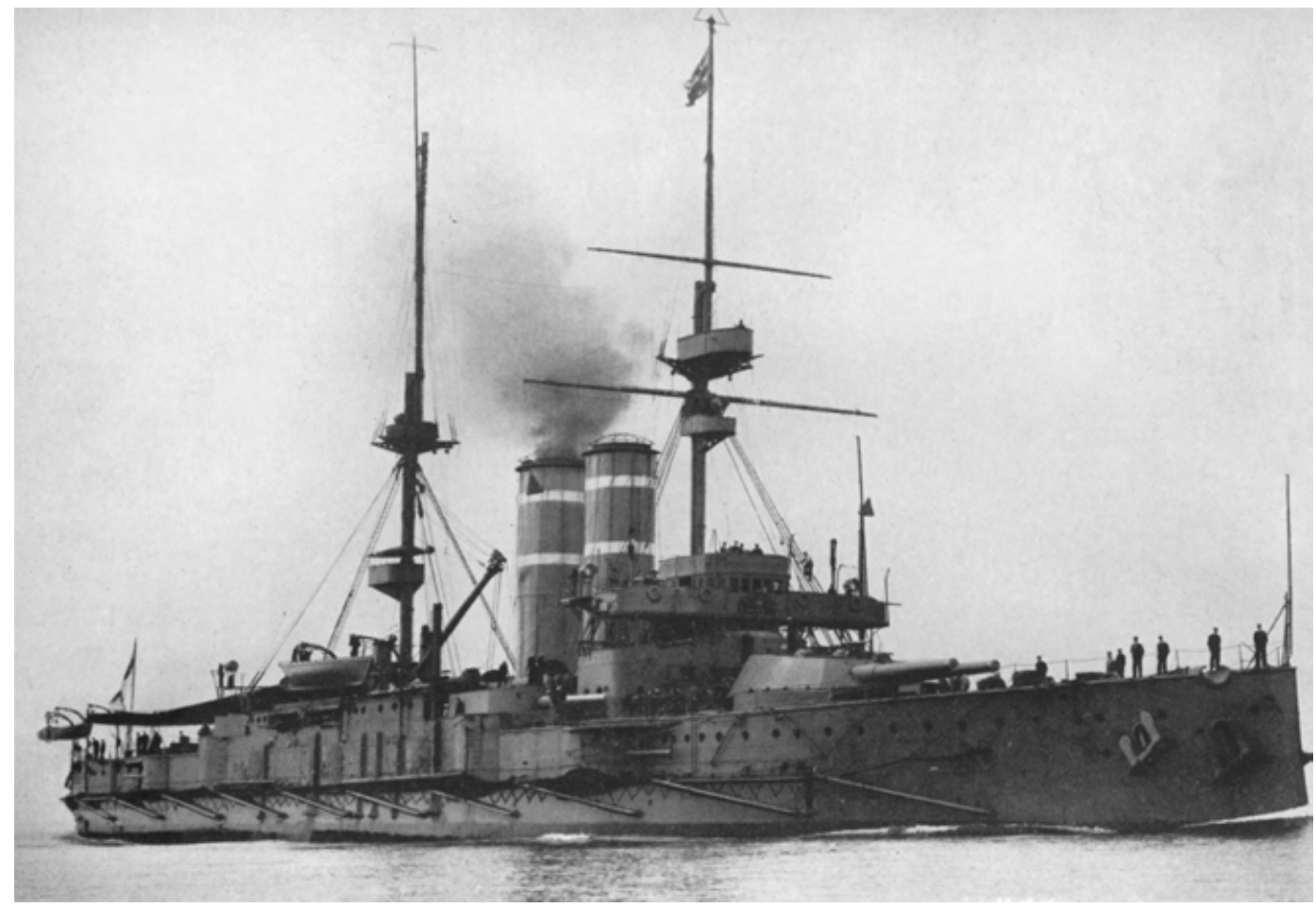

Illustration 1: A ship of the King Edward VII class, probably HMS Dominion or HMS Hindustan. Contemporary photograph, source unknown, possibly the Imperial War Museum.

The ship left Port Daniel, Quebec on the southern shore of the Gaspé peninsula very early on the morning of 16 August and sailed up Chaleur Bay to Dalhousie, New Brunswick at the mouth of the Restigouche River arriving about nine o'clock. The ship spent the entire day anchored at Dalhousie and Kingsmill and the navigating officer,

2 HMS Dominion (named in honour of Canada, the senior dominion of the Empire) was a preDreadnought battleship of the King Edward VII class (the eight ships of the class collectively were known affectionately or otherwise as the "Wobbly Eight") and displaced some 16,500 tons and was completed in August 1903 by Vickers. The ship was armed with 4 x 12 inch, 4 x 9.2 inch, $10 \times 6$ inch and $12 \times 12$ pounder guns and had a rated top speed of 18.5 knots. Hence, at the time of the incident Dominion was practically a new ship and a first line unit of the Royal Navy's order of battle. Dominion served through to the end of the First World War and was sold for scrap in 1924. See, J.J. Colledge, Ships of the Royal Navy: The Complete Record of all Fighting Ships from the Fifteenth century to the Present (Annapolis: Naval Institute Press, 1969, 1987), 110 and DK Brown, Warrior to Dreadnought: Warship Development, 1860-1905 (London: Chatham, 1997), 146-148. 
Lieutenant $(\mathrm{N})$ Basil Noake, decided to take advantage of the very clear weather to depart Dalhousie and make for Quebec City that very evening. Shortly after 6 p.m., Kingsmill ordered the anchor weighed and the ship to proceed north-east out of Chaleur Bay at 15 knots. A multiplicity of errors began to occur that culminated in the ship grounding off Souris Point on the Gaspé coast at approximately 8:55 p.m. Neither the navigating officer nor his assistant were on deck to take a bearing off the light at Belledune Light when the ship passed it and a basic error was made in misidentifying the light of a brush fire for the lighthouse at Souris Point. The light at Paspebiac Point in turn was mistaken for Souris. Paspebiac light was then mistaken for that of a passing steamer. At the very last minute, Lieutenant Noake ordered the employment of the lead line that indicated that the ship was bearing down on a shoal. He and the officer of the watch, Lieutenant Frederic Clarkson ordered an emergency turn to starboard and ordered both engines stopped and then reversed. It was too late and the ship touched ground and reversing the engines failed to get it off the shoal. Unfortunately, Kingsmill was off the bridge just finishing dinner (he had been up since four that morning) and was about to come on deck when he felt the helm go over and the engines stop then reverse. He only made it half way up the fore and aft bridge when the ship grounded. Much would be made of his absence from the deck when the incident occurred as his court martial in March the following year.

After the ship ran aground, Kingsmill ordered the engines stopped and mustered the crew and their effects on the forecastle to lighten the draught aft. The engines were worked forward, taking advantage of the rising tide and the ship was freed within two hours. The grounding heavily damaged the double bottom but there was only a minor leak. After anchoring for the night, the ship proceeded to Quebec and carried out the assigned program. Dominion was then ordered to Bermuda to make temporary repairs and then to H.M. Dockyard, Chatham for permanent work. This incident was a very unfortunate one for Kingsmill's future career prospects as he was relieved from Dominion barely three months after his court martial but was spared a period of half pay by being appointed to an older battleship, Repulse of the 1892 Royal Sovereign class. In other words, an indication of their lordships' displeasure had been broadcast not just to Kingsmill but also to the service at large. This event, therefore, must have made Kingsmill even more inclined to the possibility of entering Canadian service first as the head of the Fishery Protection Service and then as the professional founder of the Royal Canadian Navy in 1910.

The only scholarly account of this episode is to be found in the work of Richard Gimblett in a recent collective biography of Canadian naval leadership. Gimblett argued, briefly, that the incident required some explanation when Wilfrid Laurier was contemplating Kingsmill's appointment. ${ }^{3}$ Gilbert N. Tucker's official history and other secondary literature barely mention the incident at all. ${ }^{4}$

3 Richard Gimblett, “Admiral Sir Charles E. Kingsmill: Forgotten Father," in Michael Whitby, Richard Gimblett and Peter Haydon, eds., The Admirals: Canada's Senior Naval Leadership in the Twentieth Century (Toronto: Dundurn Press, 2006), 37-38.

4 Gilbert Tucker, The Naval Service of Canada (Ottawa: King's Printer, 1952), I: 150. 


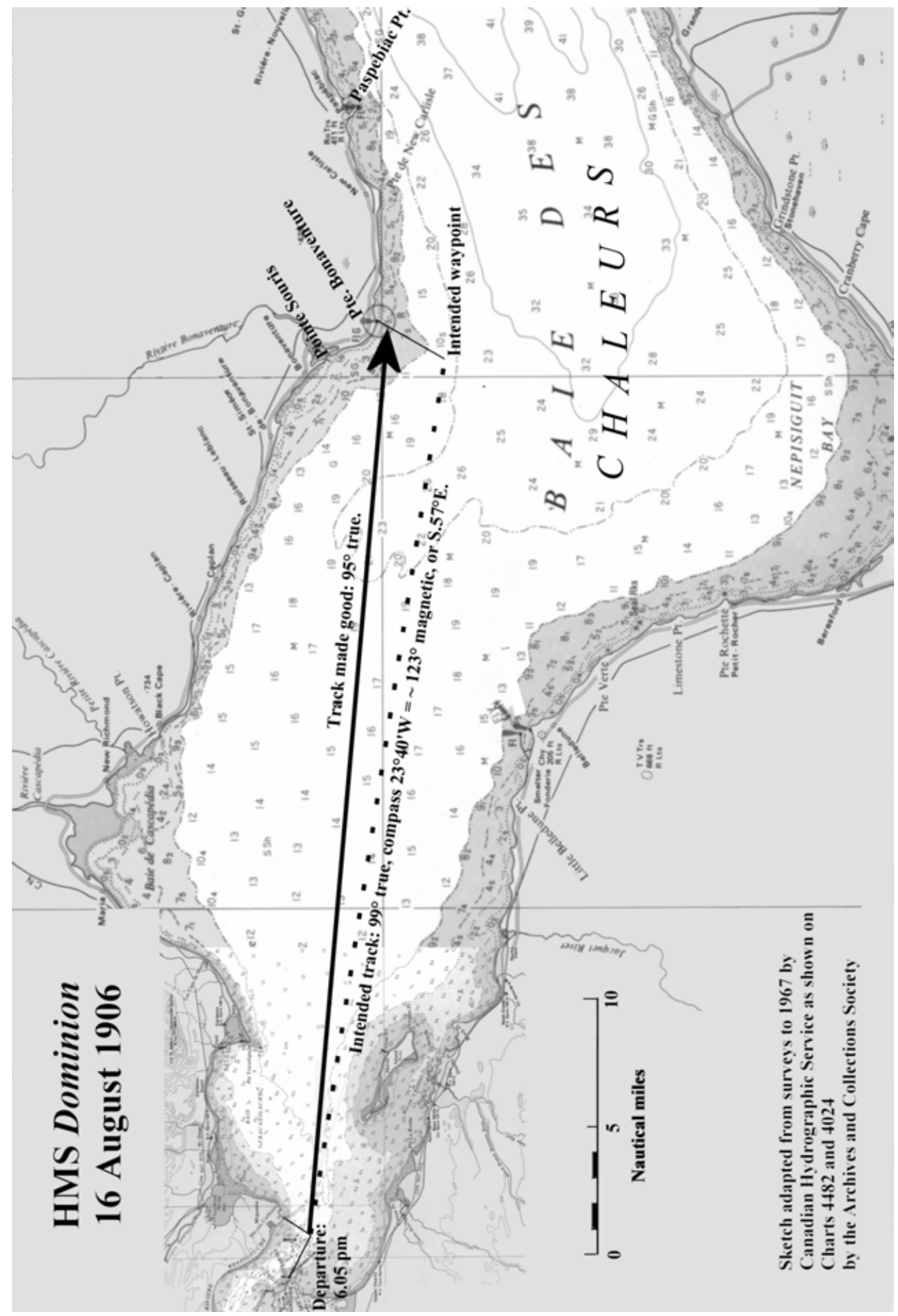


Illustration 2 (opposite): The intended track and track made good by HMS Dominion on $16^{\text {th }}$ August 1906 recreated from the various data supplied to the court martial. It should be noted that Pointe Souris was renamed Pointe de Beaubassin in 1955, but that the light is thought to have been situated nearly two miles to the south on what is now named Pointe Bonaventure [source: Service canadien de toponomie]. The divergence is only four degrees, but as noted in document 18, the margin for error was already less than intended (1.25 vice 3 miles). The probable origin of the name 'Souris', from 'échouerie' meaning a grounding, demonstrates a certain irony.

Executive Editor

[In the collection of documents that follows, the editor's commentary will be enclosed within square brackets to distinguish it from the texts of the documents.]

[Below is a copy of the signal sent to the Admiralty in London by Kingsmill advising them of the incident and the damage incurred to the Dominion. Kingsmill wisely, from a public relations point of view, indicated that he intended to complete the trip to Québec and submitted the ship should be docked at Halifax. It was also to his credit that he proposed a course of action to be taken rather than merely waiting for orders.]

\section{Document 1 - Telegram from C.E. Kingsmill to Admiralty, 17 August 1906. 5}

Following telegram has been received from H.M.S. "DOMINION", dated $17^{\text {th }}$ August. 12 p.m.

Ship grounded 9 p.m. $16^{\text {th }}$ August off Sourispoint [sic], Chaleur Bay, getting clear 11 p.m., outer bottom plates bent leaking ship requires docking.

Proceeding Quebec propose to proceed Halifax to dock after presentation ceremony. Submit Collier "Basuta" proceed Halifax if too late to stop her.

[Two days later (at Québec), after he had opportunity to examine more closely the state of the vessel and discover how the ship wandered off course and ran aground, Kingsmill submitted a detailed report. In this report, Kingsmill indicates that the navigating officer mistook one shore beacon for another.]

\section{Document 2 - Kingsmill to Admiralty, 19 August 1906.6}

H.M.S. "Dominion" at Quebec, $19^{\text {th }}$. August 1906.

Sir,

We have the honour to report, in compliance with Art. 960 K.R. \& A.I. ${ }^{7}$ that

5 Kew, England, The National Archives (TNA), Admiralty Papers (ADM) 1/7954, Kingsmill to Admiralty, 17 August 1906, p. 12. These documents are reproduced through the kind permission of The National Archives.

6 TNA ADM 1/7954, Kingsmill to Admiralty, 19 August 1906, pp. 6-10.

7 This refers to King's Regulations and Admiralty Instructions, the primary guidebook for naval officers. 
H.M.S. "Dominion" left Dalhousie, Chaleur Bay, ${ }^{8}$ at 6.5.p.m. on Thursday $16^{\text {th }}$. August 1906: course as requisite, 72 revolutions, gradually working up to 90 revolutions, from a position.

$$
\begin{array}{ll}
\text { Dalhousie Island Fixed Light. } & \text { N.41 W. } \\
\text { Magaucha Point. } & \text { N.45 E. }
\end{array}
$$

Course was shaped S.59 E. deviation 0, for a position 3 miles S.31 W. of Souris Point Light. Weather quite clear at the time. This course was checked by cross bearings of extremes of Heron Island and Carlton Light to clear Heron Shoal, no deviation from the course being observed.

At 8.20 p.m. the Navigating Officer observed a light on the Port bow, which he took for Souris Point Light. At 8.30 p.m. the bearing of the light was N.E. by E., which was reported to us. At 8.40 a cast of the lead was taken, and 16 fathoms obtained, and instructions given to sound continuously until further orders. About the same time a fixed white light was observed on a bearing S. 85 E., which was taken for Paspebiac Light, and at the same time the supposed Souris Light bore N.31 E. which corresponded with the soundings taken, and the ship was considered to be on a safe course.

The Navigating Officer, after checking the position on the chart with the cross bearings and soundings, went on to the upper bridge, and observed a fixed white light which was being passed very rapidly, and remarked to the Officer of the Watch that it must be a steamer's masthead light. (This light was Souris Light which had been mistaken for Paspebiac Light, but the Navigating Office on coming out of the Chart house did not connect this bright light, almost abeam, with the dim light he had previously taken a bearing of, and which, by his supposed position, must be still well forward.)

The Navigating Officer, not having had a second cast of the lead reported to him, then went down to the Starboard sounding machine, and noticed that bottom had been obtained with 3.5 fathoms of wire out, he immediately looked at the chart and gave the order, with the Officer of the Watch, 'hard-a-port', and the engines were stopped and then reversed, a slight tremor of the ship being noticed as the helm was put over, at 8.55. p.m. A few seconds later the ship was felt to give two of three severe shakes, and the W.T. doors ${ }^{9}$ were closed.

Reversing the engines having no effect they were stopped and boats lowered, the Navigating Officer and his assistant taking soundings round the ship. On receiving the reports of the sounding it was considered advisable to try steaming ahead with the helm hard-a-port, the ship's company being mustered with their bags on the forecastle to bring the ship up aft. The result was that the ship gradually came off the shoal with the rising tide at $10.55 \mathrm{p} . \mathrm{m}$. The ship was then anchored for the night.

While the ship was ashore the bearing of Souris Point Light was observed to be

8 That is, Dalhousie, New Brunswick.

9 Water Tight doors. 
N.1 W., and the enclosed sketches, (enclosures 1 and 2), ${ }^{10}$ give the least water obtained whilst the ship was aground, to gether [sic] with the nature of bottom.

At daylight boats were got out for the divers to ascertain the amount of damage incurred, and for the Navigating Officer and his assistant to obtain sound of the supposed position of the ship when she took the ground.

At 9. a.m. The boats were hoisted in, and the ship proceeded to Quebec.

Speed of the ship on taking ground. 15 knots.

Time on shore.

2 hours

Bottom.

Means taken of getting her off.

Gravel, and, sand \& shell.

Engines worked, ship's company mustered on forecastle, hoisted out boom boats.

Injury ship received.

As far as can be ascertained the bottom plating has received such a strain as to cause leakage, and double bottoms from forward aft as far as station 161. The stokehold plates have risen on account of frame being buckled. The filling of different compartments of double bottoms has been very gradual. It is impossible to state more exactly injury received before docking on account of strong tides, which make examination by diving alone an impossibility. The barbettes are in working order, as also are all engines. ${ }^{11}$

Wind. North-West. Force 3.

Weather

Fine, smoke-fog from bush fires at the time of grounding.

State of Sea.

Smooth.

Tide.

A flood.

Draught of water.

35'10" Forward.

37'3" Aft

Soundings.

Enclosed $^{12}$

Observed position of the ship while Souris Light N.0 W.

on shore.

4 fathoms

In our opinion the reason for the ship taking the ground was that the Officers on the

10 These have not survived.

11 Barbettes refers to the armament of the ship.

12 These have not survived. 
bridge, at the time of the accident, did not realize the denseness of the smoke, and thereby mistaking a bush-fire light for the fixed white light on Souris Point. It is only after the ship had taken ground that it was seen how thick the smoke was.

We passed this same point about 7 a.m. on $16^{\text {th }}$. Inst., and found no difficulty in fixing the ship by cross bearings, and also found no deviation from the course from Souris Light to Dalhousie, experiencing the same state of the tide.

Attached is a tracing from Chart No.1716 shewing in black the supposed positions and track between 8.30. p.m. and 8.55. p.m. and in red the true positions and track for the same times. ${ }^{13}$

We have the honour to be,

Sir,

Your obedient servants,

C.E. Kingsmill

CAPTAIN

B.S. Noake

LIEUTENANT (N).

The Secretary, of the Admiralty,

WHITEHALL, S.W.

[The ship was directed to proceed to Bermuda for essential repairs and permanent work was to be completed at H.M. Dockyard, Chatham. As can be seen below in a communication between London and Admiral Sir Gerard Noel, the dreaded Board of Enquiry was to be convened after the Dominion was to arrive back in Britain. Unfortunately for the officers of the ship, they would continue to do their duty with an official cloud hanging over their heads until they returned to England in the late winter.]

Document 3 - Evan MacGregor, Secretary of the Admiralty to Admiral Sir Gerard Noel, ${ }^{14}$ Commander in Chief, Atlantic Fleet, 3 December $1906 .{ }^{15}$

N.L. 11760.

$3^{\text {rd }}$. December 6

No. 900 .

Sir,

I have laid before my Lords Commissioners of the Admiralty your submission of the $21^{\text {st }}$ ultimo, No.1651/968, requesting further instructions as to the holding the

13 This tracing has not survived in the existing records.

14 Admiral Sir Gerard Noel was one of the most distinguished senior officers in the Royal Navy. He had an immense reputation as a ship handler and was reputed to be the last officer to handle an ironclad under full sail. Noel was also a frequent contributor and speaker at the Royal United Services Institution. 
Court of Enquiry referred to in Admiralty letter of the $3^{\text {rd }}$ September last, N.L. 8641 , to investigate the circumstances which led to the grounding of His Majesty's Ship "Dominion" off Souris Point, Chaleur Bay, Gulf of St. Lawrence, on the evening of the $16^{\text {th }}$ August.

2. I am commanded by their Lordships to acquaint you that, in view of it having been decided that the "Dominion" shall return home direct on completion of her temporary repairs at Bermuda, with a view to carrying out permanent repairs at Chatham, the Court of Enquiry will be deferred until after her arrival in England.

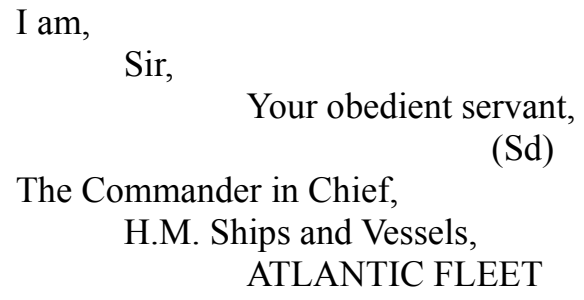

The Commander in Chief, H.M. Ships and Vessels, ATLANTIC FLEET

[On 11 February 1907 nearly seven months after the incident, a board of enquiry was convened aboard Dominion at Chatham Dockyard. The board consisted of two officers of equivalent or superior rank to Kingsmill, Commodore Frederick Stopford and Captain A. Moggridge both of whom were attached to the Nore Command. Below is an extract from the minutes of the board of enquiry where Stopford and Moggridge examined Kingsmill in regard to the events of 16 August. Kingsmill, being the commanding officer of Dominion was the first to testify. Most significant here was that Kingsmill was unable to answer the question as to why the ship diverged from its planned route while he was aft in his cabin eating dinner.]

\section{Document 4 - Extract of the Minutes of a Board of Enquiry Convened aboard H.M.S. Dominion, 11 February 1907. ${ }^{16}$}

Captain Charles E. Kingsmill having been called \& cautioned.

Q. Have you any further statement to make with reference to the grounding of HMS Dominion in addition to your report of $19^{\text {th }}$ August 1906 ?
A. No
Q. Were you satisfied with the Course S.59 E which was laid on leaving Dalhousie?

A. Yes, I was, it was laid off in my presence by the Navigating Officer. It was the reverse course to that which we came in on in the morning at the same state of the tide \& we had experienced no deviation from it.

Q. Can you account in any way for the ship being carried two miles to the northward of her course in the hours between the time of the land fix \& the time of taking the ground?

16 TNA ADM 1/7954, Minutes of a Board of Enquiry Convened aboard HMS Dominion, 11 February 1907, pp. 34-35. 
A. No, I cannot.

Q. At 8.20 was the fire that was mistaken for Souris Point reported? A. Yes, the bearing given which was about what I expected.

Q. And again was the true light which was mistaken for Paspebiac Light reported to you?

A. Yes, that was also reported.

Q. Where were you at this time?

A. In my cabin at my dinner.

Q. You had no reason to suppose the ship was standing into any danger. When did you first become aware of this fact?

A. I left the deck at 7.45 on a clear bright night leaving special orders not to forget to report the light we were expecting to see (Souris Light) and felt quite at rest in my mind as to the position of the Ship. I had personally observed for more than an hour the Officer of the Watch. He was continuously at the Starboard Compass. At 6.50, the Navigating Officer before going down to his dinner at 7 o'clock had fixed the ship by cross bearings and shown me the position of the chart, and I had observed that the ship was making a good course.

As I have stated the lights were reported to me and although I hardly expected to have seen Souris' Light quite so soon I was not surprised as the atmosphere in those latitudes is particularly clear when fine.

The wind was in the right direction for fine clear weather (A little to the West of North) and light. I suddenly felt the helm go over and knew by the noise that the ship must be in shoal water- I rushed on deck and reached half-way along the fore-and-aft bridge when I felt her bump. She had brought up when I reached the fore-bridge.

Q. Also was the sounding machine being used and were the leadsmen in the chains?

A. Yes the leadsmen were in the chains since leaving harbour, both sounding machines were ready for immediate use \& were used continuously from the light being sighted at about 8.30. I also had four months' experience of the Navigating Officer's work most of the time independent from the Fleet and had a high opinion of his ability and carefulness. I knew the Officer of the Watch as being thoroughly trustworthy to keep the ship on the course given him.

The witness's examination then concluded but remained present for the remainder of the proceedings.

[At the end of the inquiry, Commodore Stopford forwarded his conclusions to Admiral Noel. As can been seen below, Stopford advised that the since the ship was navigated without "due care," a court should be convened to try both the captain and the navigating officer. It is interesting to note here that the condemnation of Kingsmill's conduct was rather mild considering that he should have been on deck rather than below in his cabin. The bulk of the blame seems to have been directed toward Lieutenant Noake.] 


\section{Document 5 - Report of the Court of Enquiry by Commodore Frederick Stopford and Captain A. Moggridge to Admiral Sir Gerard Noel, 11 February 1907. ${ }^{17}$}

H.M.S. "Dominion" at Sheerness, $11^{\text {th }}$. February, 1907.

Sir,

We have the honour to report that in compliance with your Memorandum (Nore 410 ) of $4^{\text {th }}$ Instant we this day assembled on board H.M.S. "Dominion" to investigate the circumstances of the grounding of that ship off Souris Point, Chaleur Bay, Gulf of St. Lawrence on the evening of the $16^{\text {th. }}$ August, 1906 and find as follows: -

The ship grounding was caused by two reasons: - First, a light on shore was mistaken for Souris Light, thereby causing Souris Point Light to be mistaken for Paspebiac Light, Souris Point Light was again mistaken for a steamer's masthead light. Secondly - Sufficient allowance was not made for indraught into Cascapediac Bay.

We are of opinion that the ship was not navigated with due care and we attribute blame to lack of precaution on the part of the Lieutenant $(\mathrm{N})$, we also consider the Captain should have been on deck when in such close proximity to the land.

We have the honour to be,

Sir,

Your obedient Servants,

F.G. Stopford,

Commodore, H.M.S. "Pembroke"

A. Moggridge

Flag Captain

Admiral Sir Gerard Noel,

K.C.B., K.C.M.G.

Commander. in. Chief

[In full agreement with the findings of the board of enquiry, Admiral Noel forwarded all the records to the Admiralty. There it would be decided whether or not charges would be brought that would result in a court martial being held to try Kingsmill and his officers for causing the ship to be stranded. After the board of enquiry held by officers of equivalent experience recommended charges be brought with the concurrence of the admiral on station, it was a foregone conclusion that such proceedings would take place. It was a matter of when and how many would be charged. While the captain was always charged in such circumstances, the navigating officer and the officer of the watch would also face trial.]

\section{Document 6 - Noel to Admiralty, 11 February $1907 .^{18}$}

Submitted, observing that I fully concur in the finding of the Court. The enclosures to

17 TNA ADM 1/7954, Commodore Frederick Stopford and Captain A Moggridge to Admiral Sir Gerard Noel, 11 February 1907, pp. 30-31.

18 TNA ADM 1/7954, Admiral Sir Gerard Noel to Admiralty, 11 February 1907, p. 48. 
AL N.L. 11760 of 31 January 1907 are returned herewith.

G Noel

Admiral

[Within three days Admiral Sir John Fisher, the first sea lord, guided by the advice of the board of enquiry, directed that both Captain Kingsmill and the navigator, Lieutenant (N) Basil Noake be tried by court martial. In order to save time and expense, Commodore Stopford who headed the board of enquiry was directed to prosecute and Rear Admiral Frank Finnis of the Home Fleet was to be president of the court. Stopford was then required to draw up a charge sheet listing the accusations against the prisoners. Further, Stopford was directed to prepare the circumstantial letter outlining the reasons for the charges being laid. Much to Stopford's chagrin, the first sea lord opted a week later to include charges against the officer of the watch, Lieutenant Frederic Clarkson in the court martial proceedings. While not reproduced here, Stopford presented multiple drafts of these documents for inspection and review at the Admiralty.]

\section{Document 7 - Minute by Admiral Sir John Fisher, First Sea Lord, 16 February 1907. ${ }^{19}$}

Order Court Martial on both officers Admiral Finnis to be President, Commodore Stopford to prosecute \& prepare circumstantial letter \& charges.

J.F. ${ }^{20}$

16.2.07

Officer of the Watch also to be tried

J.F.

$22 / 2$

[Below is the warrant issued by the Admiralty to convene a court martial. This was essentially a form letter with the letterhead "Commissioners for executing the Office of Lord High Admiral of the United Kingdom of Great Britain and Ireland" which was the official title of the Board of Admiralty. The warrant was transmitted from the board to the presiding officer of the court, Rear-Admiral Frank Finnis. ]

\section{Document 8 - Warrant Transmitted from the Admiralty to the appointed President of the Court, Rear Admiral Frank Finnis, 27 February 1907..$^{21}$}

By the Commissioners for executing the office of Lord High Admiral of the United Kingdom of Great Britain and Ireland, \&c.

Whereas Admiral Sir Gerard Henry Uctred Noel, K.C.B., K.C.M.G

19 TNA ADM 1/7954, Minute by Admiral Sir John Fisher, 16 February 1907, p.48a.

20 Initials of Admiral Sir John Fisher, the first sea lord.

21 TNA ADM 1/7954, Court Martial Warrant, 27 February 1907, p.72. 
has transmitted to Our Secretary a letter dated the twenty fifth

day of February 1907, addressed to him by Commodore Frederick George Stopford

of His Majesty's Ship "Pembroke" reporting the misconduct of

Captain Charles Edmund Kingsmill,

Lieutenant Basil Stratford Noake, and,

Lieutenant Frederic William Clarkson, all

His Majesty's Ship “Dominion”

Of the said Ship; and Whereas We think fit that the said Captain Charles Edmund Kingsmill, Lieutenant Basil Stratford Noake, and, Lieutenant Frederic William Clarkson

shall be tried by Court Martial:

We send you herewith the said letter, and do hereby require and direct you to assemble a Court Martial as soon as conveniently may be, which Court, you being President thereof, is hereby required and directed to try the said Captain Charles Edmund Kingsmill, Lieutenant Basil Stratford Noake, and, Lieutenant Frederic William Clarkson

on the accompanying charge accordingly.

Given under Our hands this twenty seventh

Rear Admiral Frank Finnis, day of February 1907

Commanding the Sheerness-Chatham Division

of the Home Fleet

By Command of their Lordships

[After the warrant had been transmitted to Admiral Finnis, the court was convened on 4 March 1907. The first order of business was to entertain any objections by the prisoners to the panel of judges trying their case. This was standard procedure to ensure that that the prisoners and their "friends" would secure what they felt was a fair hearing. Kingsmill, Noake and Clarkson objected to two judges, Captains Sackville Carden and A. Moggridge. Carden had been privy to parts of the defence case as a friend of Kingsmill and Moggridge had served on the court of enquiry and it was considered that he might not be as objective as was desirable. The president of the court permitted that Carden be replaced by Captain Ralph Hudleston and Moggridge substituted by Captain Harry Hampson Stileman.]

\section{Document 9 - Court Martial Prelimaries, 4 March 1907. ${ }^{22}$}

Read the names of the officers comprising the Court.

22 TNA ADM 1/7954, Minutes of Proceedings of a Court Martial Held on H.M. Ship Acheron, 4-5 March 1907, pp. 4-5. 
The prisoners being asked whether they objected to be tried by any member of the court, Captain Kingsmill objected to be tried by Captain Carden ${ }^{23}$ of HMS "Magnificent" because he had arranged subject to the approval of the Court to be assisted by him in his defence and had already furnished him with all the details of the case and his line of defence.

Captain Moggridge of HMS "Pembroke" was also objected to by Captain Kingsmill because he had already inquired into the offence which forms the subject of the charge.

The prisoners Lieutenants Noake and Clarkson also objected to the same officers on similar grounds.

The objection to Captain Moggridge was first considered and allowed. Captain Stuart Nicholson of HMS "Dido" and Captain Seymour Elphinstone Erskine of HMS "Bedford" being unable in the opinion of the court to attend, their services being urgently required elsewhere, Captain Harry Hampson Stileman of HMS "Andromeda", the next officer in seniority was then required to sit as a member of the court, in the place of Captain Moggridge, the prisoners having stated that they had no objection to be tried by him.

The Court then considered the objection to Captain Carden and allowed it. Captain Francis William Kennedy ${ }^{24}$ of HMS "Amphitrite" and Captain Willoughby Pursey Dawson of HMS “Triton" being unable in the opinion of the Court to attend, their services being urgently required elsewhere, Captain Ralph Hudleston of HMS "Acteon", the next officer in seniority was then required to sit as a member of the Court in the place of Captain Carden, the prisoners having stated that they had no objection to be tried by him.

The prisoners made no objection to the constitution of the Court, nor to the shorthand writer.

The members of the Court, the Judge Advocate and the shorthand writer were then duly sworn.

Read the Charge and Circumstantial Letter.

[After the preliminaries had been dealt with, the business of the court commenced with the prosecutor, Commodore Frederick Stopford, reading out the formal charges against the prisoners. The first document presented was the formal charge sheet which contained the formal charges against the accused.]

23 Captain Sackville Carden acted as Kingsmill's "friend" during the proceedings. Carden went on to reach flag rank on the active list and served as admiral superintendent at the Malta dockyard and the blockading force off the Dardanelles in early 1915. He stepped down due to ill health in March 1915.

24 Kennedy ran afoul of their lordships after he wrote a highly critical and anonymous article about dispositions in the Mediterranean in August-September 1914 that appeared in The Naval Review. 
Document 10 - Charge Sheet, prepared by Commodore Frederick Stopford. ${ }^{25}$

CHARGE SHEET.

CHARGE.

For that they the said Captain Charles Edmund Kingsmill, Lieutenant Basil Stratford Noake, and, Lieutenant Frederic William Clarkson, belonging to His Majesty's Ship "Dominion", then being persons subject to the Naval Discipline Act, did, on the sixteenth day of August 1906, negligently or by default suffer the said ship to be stranded.

[Stopford then presented the substance of the prosecution's case outlining how the offense was committed.]

\section{Document 11 - Circumstantial letter by Commodore Frederick Stopford, 25 February 1907..$^{26}$}

Sir,

$$
\begin{aligned}
& \text { H.M.S. "Pembroke" at Chatham } \\
& 25^{\text {th }} \text { February } 1907
\end{aligned}
$$

I have the honour to report the circumstances attending the stranding of H.M.S. "Dominion" off Souris Point, Chaleur Bay, Gulf of St. Lawrence, on the $16^{\text {th }}$ August 1906, with a view to the trial by Court Martial of Captain Charles Edmund Kingsmill, Lieutenant (N) Basil Stratford Noake, and, Lieutenant Frederic William Clarkson, of that ship.

H.M.S. "Dominion" left Dalhousie, Chaleur Bay, at 6.5 p.m. on Thursday $16^{\text {th }}$ August 1906, course as requisite for leaving harbour, engines at 72 revolutions. After clearing the harbour, course was shaped S.59 E., Deviation 0, for a position 3 miles S.31 W, of Souris Point Light; at 6.55 p.m., the position of the ship was fixed by cross bearings.

At 8.20 p.m., the Navigating Officer (Lieutenant Basil Stratford Noake) observed a light on the Port Bow which he assumed to be Souris Point Light, whereas in reality it was a brush fire.

At 8.30 p.m., the bearing of the light was N.E. by E. At 8.40 a cast of the lead was taken and 16 fathoms obtained, and instructions were given to sound continuously till further orders. At about the same time a fixed white light was observed on a bearing S.85 E, which was taken for Paspebiac Light and at the same time the supposed Souris Point Light bore N.31 E, which corresponded with the soundings taken.

The Navigating Officer, after checking his supposed position, went to the Upper Bridge and observed a fixed white light which was being passed very rapidly. This he mistook for a Steamer's Masthead Light, whereas it was actually Souris Point Light

25 TNA ADM 1/7954, Minutes of Proceedings of a Court Martial Held on H.M. Ship Acheron, 4-5 March 1907, p. 6.

26 TNA ADM 1/7954, Minutes of Proceedings of a Court Martial Held on H.M. Ship Acheron, 4-5 March 1907, pp. 7-9. 
which had already been mistaken for Paspebiac Light.

The Navigating Officer not having a second cast of the lead reported to him, then went down to the Starboard Sounding Machine and noticed the bottom had been obtained with 3.5 fathoms of wire out. He immediately, with the Officer of the Watch, Lieutenant Frederic William Clarkson, gave the order hard-a-port, stopped and reversed both engines. A few seconds later the ship was felt to strike.

It would appear the no allowance was made for the in-draught into Cascapediac Bay in laying down the course to pass three miles South of Souris Point Light, whereas as Article 9 Page 14 of "Notes bearing on the Navigation of R.N. Ships" clearly states that:-

"In navigating coasts where the tidal range is considerable, caution is always necessary. It should be remembered that there are in-draughts to all bays and bights, although the general run of the stream may be parallel to the shore".

This in-draught took the ship so much off her course as to cause her to strike as detailed above.

It also appears that although the ship was in such close proximity to the land both the Captain and the Navigating Officer were off deck during a great portion of the time between 7 p.m. and 8.55 p.m. when the ship took the ground.

I have the honour to be,

Sir,

Your obedient Servant,

Sgd. Frederick G. Stopford

Commodore

Commander-in-Chief,

H.M. Ships \& Vessels,

THE NORE.

[After the prosecution had presented their case, the defence was given the opportunity to present their version of the events. In deference to his seniority and rank, Kingsmill gave the general line of the defence to be presented by each of the prisoners. Here the defence was given leave to demonstrate that the charges were not justified and that all three should be acquitted. It was important that all three accused present a united front and the bonds of loyalty or discipline should not be broken. Descending into fingerpointing at this point would have seriously damaged Kingsmill's reputation as an officer and a gentleman. Besides, as the captain of the ship, ultimate responsibility was his alone.]

\section{Document 12 - Preamble before Calling Witnesses. ${ }^{27}$}

\section{PREAMBLE BEFORE CALLING WITNESSES}

In opening our defence we desire to briefly set out the lines which it will take. We

27 TNA ADM 1/7954, Minutes of Proceedings of a Court Martial Held on H.M. Ship Acheron, 4-5 March 1907, pp. 75-76. 
will with the permission of the Court, each make our separate statements in defence.

\section{LINE OF DEFENCE}

1. That all the usual precautions for safe navigation in the vicinity of land were observed

2. That when the position was fixed off Heron Island, the course, (S.59.E), to pass 3 miles south of Souris Point, was shaped after careful consideration of all the circumstances, and the distance off the Point was considered a safe one.

3. That the forest fire, mistaken for Souris Point Light, and the smoke from it which blew over the real Souris Light, dimming the brilliancy of the light, masking the land, and completely obscuring Paspebiac Light were the immediate causes of the grounding.

4. (a). That the Navigating Officer took cross bearings of the lights, supposing them to be Souris and Paspebiac, sounding at the same time to verify, and that the results confirmed his conviction that the ship was approaching S P on her lain as laid on the Chart.

(b). That the stream of smoke was purely local, being blown by a light N.W. ${ }^{\text {ly }}$ breeze across the light and the land in its vicinity.

(c.). That had the wind been in any other direction the smoke would either have been clear of the lights, under which circumstances the accident could not have occurred, or the ship would have run into the smoke, in which case steps would have been taken to meet the altered conditions.

(d). 15 knots was the speed ordered because it was desirable to take advantage of the clear weather, as the St. Lawrence is much subject to fog. Under the favourable conditions of weather this speed was not excessive for a ship of the "Dominion" class, moreover the higher the speed of the ship the less the effect of any set of current across the course.

Sgd. C.E. Kingsmill

Captain

[After giving the general line of the defence, Kingsmill made the case for the acquittal of himself and his officers. First, he asserted that the course laid out by the navigating officer was a safe one under the prevailing conditions. Second, he asserted that contrary to the claim by the prosecution that no allowance had been made for the tides, that the course laid gave the ship clearance of over two nautical miles and that the charts and information available assured the safety of the chosen course. Third, admittedly a minor point, he quibbled with the definition of the waters in question as a "bight" and therefore argued that the "Notes on Navigation" relating to this point had no bearing on the situation (see Document 15). This could serve as a lever against the 
prosecution's case. Kingsmill proceeded to detail the precautions taken by the bridge crew and argued that the cause of the grounding was the presence of the smoke of a forest fire that obscured crucial navigation lights. Kingsmill also called attention to the performance of his crew after the grounding had taken place and that the ship under his command had managed to kedge itself off the shoal with minimal damage. Lastly, the captain explained his absence from the bridge. He had every confidence in both the navigating officer and the officer of the watch, he had had a very long day, and he was, in fact, off the bridge for only about 25 minutes.]

\section{Document 13. ${ }^{28}$}

\section{STATEMENT BY CAPTAIN C.E. KINGSMILL.}

I desire to submit the following statement.

1. That, although it is certain that if the course had been shaped $1 / 2$ a mile further Souris Point the Ship would not have grounded, yet under the conditions prevailing at the time the course set appeared to be a safe one.

2. The Circumstantial Letter states that "no allowance" had been made for indraught, and quotes the warning in Notes on navigation for coasts where the tidal range is considerable. I shall prove that an allowance of 2 miles was made, and the Tide Tables shew 5 feet as the Rise at Neaps ${ }^{29}$ at Carleton. This cannot be called "considerable." I desire to lay special stress on the information which was available concerning the set and rate of the Tides in Chaleur Bay. Paragraph 6, page 527, St. Lawrence Pilot, 1906, states "the tidal streams are regular and rate seldom amounts to one knot in an hour". This had been read by me, and to gether [sic] with the information of Chart 1715 Chaleur Bay, was carefully considered by Lieutenant Noake and myself before shaping the course. There are several pairs of tidal arrows on this chart, one about midway between Heron Is. and Souris Point indicates that the set is straight up and down the fairway, and in line with the course steered, S.59.E, Three others are marked close inshore, these last shew a set up the coast at a distance of about $1 \frac{1 / 4}{4}$ miles from it. Thus the impression is distinctly conveyed that the Tides in this part of the Bay of Chaleur are regular and weak, which is emphasized by the fact that at Carleton the Spring Rise is 8 feet and at Neaps only 5 feet at Souris it would be less, 6 feet and four feet. The Tides were Neap on $16^{\text {th }}$. August, and within 24 hours after the weakest.

A fair analysis of their effect on the run down from the position at 6.55 p.m. to 3' south of Souris Point would be. For the first 4 miles slack and beginning to flow, the next 18 running directly opposite to the course steered, at a rat of

28 TNA ADM 1/7954, Minutes of Proceedings of a Court Martial Held on H.M. Ship Acheron, 4-5 March 1907, pp. 77-84.

29 Neap tide - the period during the lunar month during which the range between high and low waters is the least, often leading to the assumption that tidal currents will be at their slackest. 
about $1 / 3^{\text {rd. }}$ knot, for the last 5 miles it should set gradually more to the N.W. ${ }^{\text {d }}$ and as far as can be judged at about the same rate. Thus only in the last five miles could the tide be expected to run at all athwart the course. The actual tidal set at 8.42 p.m. an investigation proves to have been about N.N.W. $3 \frac{1 / 4}{4}$, resolving this, gives about $2 \frac{1 / 4}{4}$ miles North and 1 mile West. The Northing could have only taken place in about the last 5 miles, (22 minutes run at 15 knots), a rat greatly above anything I could expect or apprehend from the information at my disposal.

3. Draw a line from Carleton to Bonaventure Point, which in agreement with the Circumstantial Letter, I will call Cascapediac Bay, the average distance of the land on the North side of this line is about 4 miles, to the South the average is 8 miles. Now then can Cascapediac Bay be called a bight within the meaning of the Notes on Navigation?

4. I had passed 3 miles south of Souris Point at 6.52 a.m. on that day proceeding from Port Daniel to Dalhousie. It was then about an hour after Low Water. We observed that there was not any set across the course, which was shaped for a certain position off a danger we were approaching, and on arrival there altered on the reach for Dalhousie.

5. As a matter of fact the total set expected, as worked out by the Navigating Officer, was N.W. by W. $1 / 2$ to $3 / 4$ knot. After leaving Dalhousie the ebb was still running past Maguacha Point, at 6.30. p.m., which was taken into consideration.

6. The Northern shore of the Gulf is the Navigation side; the principal Lights and Fog Signals are on that coast.

7. The cause which prevented this set to the N.W. ${ }^{\text {d }}$ being discovered in time was undoubtedly the existence of the forest fire which appeared as a fixed light in the expected direction of the Souris Fixed Light, the smoke from it blown by the light wind partially obscured Souris Point Light and made it appear, when sighted, to be much more distant than it really was, (about 3 miles). This combined with the fact that it was approximately on the bearing that Paspebiac Fixed Light should be, caused it to be mistaken for that light. A cross bearing of this phantom light and of the supposed Paspebiac Fixed Light taken at about 6.42 p.m. verified by a sounding of 16 fathoms, agreed very well with the run since 6.55 p.m. and placed the ship on her line. After the ship grounded it was found that Paspebiac Light was not in sight though only $8 \frac{1}{2}$ miles distant, being obscured by the smoke then envelopped the ship. I submit that this extraordinary combination of circumstances might have easily deceived the most experienced of Navigators.

8. The action of the Navigating Officer and the Officer of the Watch in putting the helm hard-a-port just before the ship took ground, caused her to slew to starboard to the Southward after touching. Boats were immediately lowered and soundings taken round the ship, the deepest water being off the starboard bow, and I steamed the ship off by going ahead as the tide rose. The boom boats were hoisted out to lighten the ship and to lay out anchors, if required, but this was not found 
necessary. The work ordered was carried out smartly by Officers and Ship's Company, and in a quiet and orderly manner. The work in the Engine Room Department was also particularly satisfactory. The ship was examined below and wells sounded, the only leak through the inner bottom shewed in the foremost stokehold where the oil fuel, which is stowed in the double bottoms, was forced up. The fires in the in this stokehold were drawn quietly to avoid any chance of accident. The Ship was then anchored for the night in $9 \frac{1}{2}$ fathoms.

At daylight the following morning the boats were sent away to sound and, if possible, verify the position of the ship when aground. The double bottoms were found to be full as far aft as 136 station, and the draught had increased Forward 1' 6", and decreased 0' 3"Aft. Divers were sent down to see of they could find any rent, but this was not expected from the nature of the bottom which was hard sand and shell and indication of rock. After another careful examination of the ship I determined to proceed to Quebec and there carry out the Admiralty programme.

9. The Circumstantial Letter states the Captain and Navigating Officer were off deck during a great portion of the time between 7 p.m. and 8.55 p.m. With regard to this I wish to submit that the period was 25 minutes only, between 7.45 and 8.10 p.m. and that land was in sight and had been in sight since leaving Dalhousie on a fine clear night. The bush fire was solely and purely the cause of the set to the Northward not being discovered, and not the fact that a proper look-out was not being kept. The Navigating Officer was on the bridge when approaching the light, and although I am quite aware that the Captain is responsible for the safe conduct of the ship, I fail to find any article in the King's Regulations and Admiralty Instructions which lays down that the Captain is to be always on the bridge when in light of land.

10. After leaving Dalhousie I remained in the Chart House and on the Bridge until 7.45 p.m. and personally assured myself that the Officer of the Watch was paying attention to his compass, that the leadsmen were in the chains and the lookouts properly placed, and felt assured that the ship was being steered her proper course. It was a clear bright starlight night, the lights on out Starboard hand shewing clearly and I could not possibly imagine that we should not see clearly those lights were specially looking for, viz., Souris Fixed Light and Paspebiac Fixed Light. There was before me a night on coasting and I had had already a very long day, from 4.30 a.m. when I left Port Daniel, taking the ship to Dalhousie, and doing the work entailed by a ceremonial visit and I feel perfectly satisfied now, after many months thinking over the matter, that I did not in any way fail in my duty in going down to my dinner, having every confidence in the Officer of the Watch and Navigating Officers. Especially in Lieutenant Noake whom I consider a very careful Navigating Officer, and an excellent pilot, so much so that I did not deem it necessary to engage a local pilot for the St. Lawrence. The usual standing orders for reports to be made to me were in force, and at 8 p.m. I sent a special message to remind the Officer of the Watch to report the lights which were expected to be seen. At 8.30 p.m. I received a report by $\mathrm{Mr}$. Spurgin, Midshipman, from the Officer of the Watch that Souris Point Light was sighted, bearing N.E. by E. - again at 8.45 that Paspebiac Light was sighted 
S.85.E., a correct bearing to my mind at the time. I was then about to go on deck but hearing the helm go over suddenly I hastened up to the bridge, and felt the ship ground when I was about abreast the funnels on the fore and aft bridge.

It had been shewn to the Court that there were no soundings taken previous to 8.40 p.m. I beg to submit that we were passing along the land on a clear night and I had no suspicion whatever of smoke or haze being present, and consequently expected to see Souris Fixed Light and Paspebiac Fixed Light, our guides for safe navigation. It was only on directly approaching the land that the soundings were of much value.

A great deal of evidence has been given to shew that there was smoke on the hills seen before dark and afterwards. I wish the Court to believe that I had no knowledge whatever of the presence of smoke. I do not wish to infer that had I seen it would have placed the situation in a different light to me at the time. The Officers of the Watches did not consider it of enough importance to take steps to let me know. Of course it is easy to be wise after the event and had I known it it may have made some difference. These bush fires which the Signalmen report having seen on the land were in sight to them while I was on deck but I did not see them.

It is I believe the custom of the Service, when enquiring into the grounding of one of His Majesty's Ships, to consider also the steps taken to get her off and ensure her safety afterwards. In the exceptional circumstances of this case the incident cannot be considered to have ended till the ship arrived at Bermuda, so I will refer briefly to our experiences in the interval.

After the safety of the ship had been considered, the Admiralty Programme was my important duty, which was to proceed to Quebec to receive the presentation of plate which the Canadian people were giving the ship, to remain there a fortnight to give them an opportunity of seeing the ship, and to carry out the numerous entertainments, which were indispensable to such an occasion, This duty was therefore performed and in obedience to orders received there I left on $3^{\text {rd }}$. September for Bermuda, and on the $8^{\text {th }}$. when nearing the Island I was set by a West Indian hurricane, which prevented me entering The Narrows, and I was obliged to remain at sea. Proceeding very slowly on one engine, keeping the ship, as much as possible, with the sea just before the beam to longitudinal strain. The ship behaved splendidly, the oil fuel exuding from the damaged bottom certainly helping to prevent heavy seas breaking on board. The wind and sea moderated on the morning of the $10^{\text {th }}$. And I arrived in Murray's Anchorage, Bermuda, that afternoon.

Sgd. C.E. Kingsmill

[After the presentation of the defence case, Kingsmill was called to the stand to give his evidence. Most unusual here was the prosecution's reluctance to cross examine Kingsmill's testimony and the members of the court were forced to do so themselves.] 
Document 14 - Testimony of Captain Kingsmill. ${ }^{30}$

CAPTAIN CHARLES EDMUND KINGSMILL, called and sworn, gave evidence as follows: -

I propose to swear to the truth of the statement I read, and I have got here an epitome of my evidence. On the $16^{\text {th }}$ August 1906, I weighed from Port Daniel at $4.45 \mathrm{a} . \mathrm{m}$. and proceeded up the Ristagouche [sic] to Dalhousie, where I anchored at about 9.50 a.m. I remained there until 6.5 p.m. and left there after consulting the Navigating Officer as to whether we should proceed out of the Bay that night. We came to the conclusion that we should do so on account of the very fine weather which was prevailing, and taking into consideration the liability to fog in the St. Lawrence, we proceeded. I gave orders to proceed to 72 revolutions as soon as the ship was turned and told them in the engine room to work up to 90 revolutions. At about 6.30 p.m. we shaped our course, the ship then going 90 revolutions. They reported 90 revolutions almost immediately after that from the engine room. The course was laid down in my presence by the Navigating Officer, and we discussed what indraught we were likely to get, or what tide we were likely to get against us, and a course was laid to pass three miles S. and something W. of Souris Point light. I remained on the bridge, I think on the upper bridge, until after 7 p.m. when I went down with the Navigator to the charthouse and there looked over the chart again with his last fix, which was taken at 6.55 p.m. I remained in the charthouse looking over the sailing direction then for some time - how long I do not know, but I know that I remained on the bridge or in the charthouse until 7.45 p.m. with the exception of perhaps five minutes when I went below to change a coat. I personally noticed the officer of the watch, and found that he was paying strict attention to his course, and I know the officer of the watch as being an officer who done nothing else particularly on the bridge except pay attention to his course. He has not been brought up in our service, but had a Royal Naval Reserve bringing up, and he paid strict attention to his course, and I thought at the time that that was all right. At $7.45 \mathrm{I}$ had a final look round and went down to my dinner. At 8 o'clock the midshipman of the watch came down and gave me the Navigating Officer's 8 o'clock position, and reported 8 o'clock. I was then at my dinner. I told him I wished to know as soon as Souris Light was sighted, and at 8.30 Mr. Spurgin, midshipman of the watch came down and reported Souris light bearing N.E. by E. At about $8.45 \mathrm{Mr}$. Spurgin came down again and reported Paspebiac light bearing S.85 E. which appeared to me about right. I just finished my dinner and was getting ready to go on deck, but I had not really left the table when I felt the jar which I always feel when the ship is in shoal water and the helm goes over. I rushed on deck and felt the ship ground as I was on the fore and aft bridge. When I arrived on the bridge the ship had stopped and I found her enveloped in a dense fog.

30 TNA ADM 1/7954, Minutes of Proceedings of a Court Martial Held on H.M. Ship Acheron, 4-5 March 1907, pp. 94-96. 
The Prosecutor declined to cross-examine this Witness.

By the Court:

Q. You have detailed the good work done by your officers and men subsequent to the grounding. Do you wish to mention the name of anyone particularly deserving of praise?--- No. It was not a case in which there was anything very much to be done.

617. Q. After the ship grounded could you see the shore? --- No.

618. Q. Have you any general order to the Navigator as top the distance of passing dangers or points of land? --- No.

By Lieut. Noake:

619.Q. Why do you consider 6 revolutions to the knot to be the correct estimate of speed?--- From my personal knowledge of the behaviour of the ship. In smooth water the ship makes one knot for six revolutions at the draught she was then in, and the engine register will show that.

The Witness's evidence was read over.

The Witness withdrew as such.

[Prior to a verdict by a court, any documents that might mitigate the judgement would be accepted and examined. In the case of ratings and junior officers certificates of good conduct and previous contributions to the service would be submitted. Kingsmill submitted two documents (Nos. 15 and 16). Document 15, is a telegram from the Admiralty to Admiral Noel that had been forwarded to Kingsmill. The Admiralty expressed their satisfaction with the performance of the officers and men in co-operating with the dockyard in Bermuda to repair the ship. This would show that although an accident had been suffered the captain and crew were still competent and made every effort to repair the damage from their own resources. The second document was a statement written by Kingsmill detailing the success he had in commanding other ships throughout his career and how much the whole ordeal of the grounding, the board of enquiry and the court martial weighed upon him.]

\section{Document 15 - Admiralty to Noel, 1 March $1907 .^{31}$}

C.N. 19505/07.

Nore 789.

Admiralty

$1^{\text {st }}$. March 1907.

Sir,

I am commanded by My Lords Commissioners of the Admiralty to acquaint you that they have received with satisfaction a report of the saving in time and cost, and the efficient manner in which the temporary repairs to H.M.S. "Dominion" were recently carried out at Bermuda.

31 TNA ADM 1/7954, Minutes of Proceedings of a Court Martial Held on H.M. Ship Acheron, 4-5 March 1907, p.116. 
My Lords desire that an expression of their Appreciation of the energy shown by the Officers and men of the "Dominion" in co-operation with the Dockyard, may be convoyed to them.

I am,

Commander-in-Chief,

Your obedient Servant,

(Sd') C.I. Thomas

H.M. Ships \& Vessels, THE NORE.

\section{Document $16 .^{32}$}

Statement by Captain C.E. Kingsmill in lieu of Certificates \&c.

I desire to lay before the Court that since the Autumn of 1889 I have had the honour of successfully commanding the following H.M. Ships

$$
\begin{aligned}
& \text { "Cormorant" } \\
& \text { "Goldfinch" } \\
& \text { "Archer" } \\
& \text { "Gibraltar" } \\
& \text { "Mildura" } \\
& \text { "Scylla" } \\
& \text { "Resolution" } \\
& \text { "Majestic" }
\end{aligned}
$$

also that this Court Martial has been hanging over me for the last six months during which the programme at Quebec was carried out under what were to me trying circumstances, with I have reason to believe, complete success, and the behaviour of the ship's company during the visit was the subject of high praise in the Canadian Press. Then the ship was carried to Bermuda in her injured condition through the bad weather already referred to, and finally, after temporary repairs, to England.

These circumstances together with the lasting blow to Professional pride that so fine a ship should have $b$ en injured while under my command, have imposed upon me a good measure of suspense and anxiety.

\section{C.E. Kingsmill}

[After the court had listened to the evidence, read supplied documents and listened to the statement of the prisoners, the court was cleared for deliberations of guilt or innocence. The document below is a standardized typed form with spaces left for the findings. Both Kingsmill and the navigating officer, Lieutenant Noake, were found guilty of negligence in the grounding of the ship and sentenced to be severely reprimanded. The officer of the watch, for reasons not given, was found to be innocent of the charges. After

32 TNA ADM 1/7954, Minutes of Proceedings of a Court Martial Held on H.M. Ship Acheron, 4-5 March 1907, p. 117. 
the two prisoners were found guilty, the court was again cleared for the members to consider the sentence to be handed down. Both prisoners were sentenced to be severely reprimanded but the court stopped short of dismissing them from Dominion which would have sounded the death knell for both their careers.]

\section{Document 17 - Verdict. $^{33}$}

The prisoners having nothing further in their defence, the Court was cleared to consider the Finding.

\section{FINDING.}

The Court finds that the charge against Captain Charles Edmund Kingsmill and Lieutenant Basil Stratford Noake is proved in that they did by default suffer His Majesty's Ship "Dominion" to be stranded. The Court also finds that the charge against Lieutenant Frederic William Clarkson is not proved, and therefore acquits him of the same.

The Court was re-opened; the prisoners brought in; the prosecutor, witnesses and audience admitted.

The Prosecutor had no entries in ship's log or other official documents to produce against Captain Kingsmill or Lieutenant Noake.

The Court was then cleared and proceeded to frame the Sentence.

\section{SENTENCE.}

The Court having found the charge against Captain Charles Edmund Kingsmill and Lieutenant Basil Stratford Noake is proved and adjudges them the said Captain Charles Edmund Kingsmill and Lieutenant Basil Stratford Noake to be severely reprimanded, and having also found that the charge against Lieutenant Frederic William Clarkson is not proved, and therefore acquits him of the same.

Sentence dates this fifth day of March 1907.

Frank Finnis
NA Greet
CH Coke
JCA Wilkinson
Charles Dundas of Dundas
AH Christian
Henry Stileman
Harry H Torlesse
R Hudleston

33 TNA ADM 1/7954, Minutes of Proceedings of a Court Martial Held on H.M. Ship Acheron, 4-5 March 1907, pp. 127-129

34 President: Rear Admiral Frank Finnis, Rear Admiral Home Fleet; Captain Thomas Young Greet, HMS Pembroke (base ship for the Chatham Dockyard); Captain Charles Henry Coke, HMS Wildfire (steam tender, base ship at Sheerness); Captain Julian Charles Allix Wilkinson, HMS London (battleship, 1899); Captain Charles Dundas of Dundas, HMS Ocean 
The Court was re-opened; the Prisoners brought in, the Prosecutor, Witnesses and Audience admitted, and Sentence pronounced accordingly.

The President declared the Court dissolved.

AR Parker ${ }^{35}$

Officiating as Deputy Judge Advocate.

[The court did not have the power of imposing a sentence on its own authority. All court martial verdicts and sentences were subject to the review of the Board of Admiralty that confirmed or modified the sentences handed down. Prior to confirming the sentence, the board took the advice of the hydrographer of the navy and the judge advocate of the fleet. Mostyn-Field, the hydrographer, wrote a minute (Document 18) analyzing the conditions which lead to the incident and agreed with both the necessity for a court martial to be convened in this case and that the sentence itself was appropriate. J. Hoste, the judge advocate of the fleet, was in broad agreement that the sentence was appropriate but considered some of the procedures to be highly irregular. He was most critical of the failure of Commodore Stopford to cross-examine the prisoners and the nonparticipation of several officers who had been nominated to the court but pleaded pressures of other duties (see Document 9).]

\section{Document - 18 Report by the Hydrographer, 15 March $1907 .^{36}$}

From the evidence given at the Court Martial it appears that H.M.S. "Dominion" left Dalhousie at 6.5 p.m. on $16^{\text {th }}$. August bound for Quebec, that when outside the harbour the course was shaped S.59 $\square$ E. and the vessel proceeded at 90 revolutions; which was estimated to give a speed of from $141 / 2$ to 15 knots. At 6.55 p.m. cross bearings places the vessel in the position shown on the attached Admiralty Chart No. 1715 and it was estimated that the course being steered would take the ship $3 \frac{1}{2}$ miles outside Souris Point light, but this was a mistake, as the course steered only took the ship $2 \frac{1}{3}$ miles off the light and passed about $1 \frac{1}{4}$ miles off the danger line of 5 fathoms. At about 7.30 p.m. the Navigating Officer left the deck to go to his dinner and did not return to the deck until 8.10 p.m., and although there was a Lieutenant doing duty as Assistant Navigator, he was also off the deck from 7 p.m. until the Navigating Officer returned to the bridge at 8.10 p.m. They were therefore both off deck when passing Little Belledune point light and failed to fix their position by it and Heron Island light when the first named light was abeam. It is said this Belledune light was not easily distinguishable, but an angle from Heron Island light would readily have shown its position.

(battleship, 1898); Captain Arthur Henry Christian, HMS Duke of Marlborough; Captain Harry Hampson Stileman, HMS Andromeda (armoured cruiser, 1897); Captain Henry Holland Torlesse, HMS Victorious (battleship, 1895); Captain Ralph Hudleston, HMS Actaeon.

35 Fleet Paymaster Alfred Ramsay Parker, secretary to Admiral Noel.

36 TNA ADM 1/7954, Minute by Hydrographer, 15 March 1907, pp. 77-78 
It also appears in evidence that several Bush fires were seen on the Northern shore, that the weather was very clear and lights on the South shore clearly visible, though the smoke from the Bush fires would appear to have shrouded somewhat the lights on the North shore.

At 8.30 a light was sighted bearing N.E. by E. and this was mistaken for Souris light, though a little consideration would have shown that had this been Souris light on that bearing, the ship must have run 26 miles since 6.55 p.m. or at a speed of 16.4 knots, i.e. nearly $1 \frac{1}{2}$ miles an hour faster than the estimated speed of 15 knots, and this with the flood stream against the vessel. Between 6.40 p.m. and 6.50 a second light was seen bearing S.85 E., and this was mistaken for Paspebiac light. It really was Souris light. The sounding machine was started, and a sounding of 16 fathoms obtained, but when the lead was again let go it was seen by the wire that the vessel was in shallow water and the helm was put hard a port and the engines stopped \&c. but this action was taken too late to prevent the "Dominion" running aground in the position shown.

The cause of the accident was due -

1. To an insufficient study of the variation on the chart. The approximate lines of equal variation drawn in blue show that a mean allowance of 23 " 40 ' W. should have been allowed on the course from 6.55 p.m. and that this course only took the vessel a little over a mile off danger.

2. To the Navigating Officer and his assistant being both off deck during the time the vessel was passing Belledune light, so no check was obtained of the course the ship was making good when that light was abeam.

3. To the neglect of allowing for an indraught into Cascapediac Bay and part of the defence is based on the assertion that no such indraught should have been allowed. Whereas it is quite evident that a slight indraught of about half a knot was experienced.

4. To the mistake respecting Souris Point light, which it is probable had the speed been considered would not have occurred.

It appears to me that the finding of the Court Martial is quite warranted from the above considerations.

$15^{\text {th }}$ March 1907.
A. Mostyn-Field
Hydrographer

\section{Document 19 - Minute by the Judge Advocate of the Fleet, ${ }^{37} 9$ March $1907 .{ }^{38}$ \\ COPY OF THE MINUTE OF JUDGE ADVOCATE OF THE FLEET DATED $9^{\mathrm{TH}}$ MARCH 1907.}

\footnotetext{
37 Mr. J. Hoste

38 TNA ADM 1/7954, Copy of the Minute by the Judge Advocate of the Fleet, 9 March 1907, pp. 80-81.
} 
Read. With the exceptions mentioned below the proceedings are quite regular. The absence of Captains Nicholson, Elphinstone, Kennedy and Dawson was not in accordance with the existing Regulations but this matter has been fully dealt with in the proposed new regulations and the point is mentioned here to show that it has not been overlooked. ${ }^{39}$ The examination of Commander (N) Dawson and Lieutenant $(\mathrm{N})$ Brandon seems to have been conducted in an unusual and unsatisfactory manner. The witnesses cannot be properly examined together and the awkwardness of the proceeding seems to have led to the request of Captain Kingsmill at page $63 .^{40}$ If his suggestion had been acted on however, it would have led to the unseemly exhibition of one witness contradicting his callaborateur then and there. The proper course to pursue in these cases is that provided in the new regulations, viz., to examine the witnesses separately so as to give both the prosecutor and the prisoners full opportunity if they desire it of effectively examining both witnesses. But if the prosecutor has no reason to expect a divergence of opinion, it wd be quite regular for him to ask the second expert whether he agrees with the evidence of the first, and then to leave to the prisoners the opportunity of cross-examining.

I observe that the prosecutor failed to cross-examine Captain Kingsmill and Lieutenant Noake, and in my opinion failed in his duty in this respect, with the result that the Court had to cross-examine them which seems to me an undesirable position into which to place the judges.

The finding appears to me to be justified by the evidence and the sentence is in due form and within the powers of the Court.

[After the various officials in Whitehall made their comments, the Board of Admiralty considered the findings and elected to confirm the sentences. The fourth sea lord, Admiral Sir Alfred Winsloe, was rather critical of the court's sentence and believed that both Kingsmill and Noake should have been dismissed their ship in addition to receiving a reprimand. The second and first sea lords concurred with the Winsloe's opinion. However, it would have been highly questionable and against regulations to increase the punishment meted out to Kingsmill and Noake.]

\section{Document 20 - Minutes by Admiral Sir Alfred Winsloe, Fourth Sea Lord, Admiral Sir Charles Drury, Second Sea Lord and Admiral Sir John Fisher, First Sea Lord, 16 March 1907. ${ }^{41}$}

I concur with the report of the Hydrographer and would add.

(1) That at 6.55 the course was shaped unnecessarily close to Souris Point.

\footnotetext{
39 See Document 9 for the procedure in selecting members of the Court.

40 Both of these officers were examined together on the details of pilotage regulations. Kingsmill had requested that in the event that the two witnesses disagreed the dissent would be noted in the official record of the proceedings.

41 TNA ADM 1/7954, Minutes, 16 March 1907, p. 79
} 
(2) That when the weather became hazy no steps were taken to ascertain the position, nor was speed reduced so that good soundings could be taken

(3) Both Navigating Officers should not have been below at the same time at dinner.

(4) That under the circumstances, knowing that the ship was steaming 15 knots to pass close to a point of land off which a dangerous shoal ran out about one mile, the Captain and Lieut-(N) were guilty of grave neglect of duty in leaving the deck as they did.

(5) I concur in findings of ct martial but I consider that both Captain and Lieut $\mathrm{N}$ both [should?] have been dismissed from HMS Dominion ${ }^{42}$

Fully concur with the $4^{\text {th }}$ Sea Lord $^{43}$

Concur 16.3. $7^{44}$

[The following information was entered into Kingsmill's service record at the Admiralty. Upon entry into Royal Navy service, each officer was given a fresh page to record their performance as a cadet and officer and contained précis of performance evaluations. This information was useful in assessing the abilities of each man and his likely success in higher ranks with greater responsibilities.]

\section{Document 21 - Service Record of Charles Edmund Kingsmill. ${ }^{45}$}

4 March 07 tried by Court Martial for suffering "Dominion" to be stranded on 16 August 06: default proved. Sentenced to be severely reprimanded N.L. 2343/07. Board considered sentence lenient.

\section{Conclusion}

While Captain Kingsmill was convicted of causing the grounding of HMS Dominion in August 1906, and it was apparent that he had been guilty of misconduct in the handling of the ship in this instance, it was also readily apparent that much had been done to spare him indignity. The president of the board of enquiry, Commodore Stopford, seemed to place much of the blame on the navigator, Lieutenant Noake. Then, Stopford, as prosecutor at the court marital, did not cross-examine Kingsmill's testimony. After conviction Kingsmill was allowed to remain in command of Dominion for some months, and, with virtually no time on half pay, was then given another command, even if of an older ship. In other words, his career was not over. That being said, it became increasingly apparent that Kingsmill's career was likely to be a fairly short one as he would be retired upon promotion to rear-admiral when he reached the head of the captains' list. Kingsmill had already made favourable contacts with the Liberal government of Wilfrid Laurier when Dominion had transported the body of Raymond

$42 \quad$ Admiral Sir Alfred Winsloe, Fourth Sea Lord

43 Minute by Admiral Sir Charles Drury, Second Sea Lord

44 Minute in the handwriting of Admiral Sir John Fisher.

45 TNA ADM 196/38, Service Record of C.E. Kingsmill, p. 755. 
Préfontaine, the minister of Marine and Fisheries, earlier in $1906 .{ }^{46}$ The possibility of entering Canadian service with prospects for a renewed career must have seemed all the more attractive with the events that unfolded later in 1906 and 1907. In this way, the grounding and the court martial helped bring a very distinguished and able officer to lay the foundations of the Royal Canadian Navy. 